\title{
Corporate Social Responsibility and Business Ethics: A Conceptual Framework
}

\author{
Abhishek Kumar Jha \\ L. N. Mithila University, Darbhanga, Bihar, India.
}

CITATION: Jha, Abhishek Kumar (2020), "Corporate Social Responsibility and Business Ethics: A Conceptual Framework”, MERC Global's International Journal of Management, Vol. 8, Issue 4, pp. 162-166.

ARTICLE HISTORY: Submitted: May 10, 2020, Revision received: June 16, 2020, Accepted: July 03,2020

ARTICLE TYPE: Review paper

\begin{abstract}
In common parlance, the term 'business ethics' refers to the set/systems of principles and rules of conduct applied to business. In practice, the term has been used to describe the do's and do not for business, the various things that business should or should not do, viz., not violating any law, avoiding unethical practices, making donations to charitable causes; taking up development projects in backward areas, paternalism towards employees, good public relations, etc. However, the contours of business ethics have undergone a sea change over the past couple of years. Far from being a set of abstracts do's and do not for business, business ethics have come to represent a set of fundamental beliefs about business. The opinion is growing that business owes a debt to society and that it should repay it in a transparent and easily perceivable manner. No doubt, business - a social organisation cannot and should not be allowed to conduct itself in a manner detrimental to the interests of the cross-sections of the society as also to the various constituents of business at large. This paper focuses on corporate social responsibility shifts towards business ethics.
\end{abstract}

KEYWORDS: Business ethics, Corporate social responsibility, Human values, Work environment.

\section{BIBLIOGRAPHY}

1. Frederic, Post and Davis (1992), Business and Society, Mc-Graw Hill, New York.

2. Kaur, Manmeet and Singh, Rajpal (2016), "Corporate Social Responsibility: A Step towards Fashion or Future?”, MERC Global's International Journal of Management, Vol. 4, Issue 1, pp. 01-05.

3. McWilliams, A. and Siegel, D. (2001), "Corporate social responsibility: a theory of the firm perspective", Academy of Management Review, Vol. 26, Issue 1, pp. 117-127.

4. Misha Rajan (2009), Human Values, University Science Press, New Delhi.

5. Rituparna, Raj (2001), Business Ethics, Himalaya Publishing House, India.

6. Sherlekar S. A. (1997), Management Value Oriented Holistic Approach, Himalaya Publishing House, India.

7. Singh L.P. (2004), "Business Ethics in India and Abroad: An Overview", The Journal of L.N. Mithila University, Darbhanga, pp.18-19. 